\title{
Training of Artificial Meat Processing from Soybeans as a Source of Protein for women Groups in Syahmad Village, Lubuk Pakam Sub-District
}

\author{
Tiar Lince M. Bakara ${ }^{1 *}$, Urbanus Sihotang ${ }^{1}$ \\ ${ }^{1}$ Departement Nutrition, Politeknik Kesehatan Medan
}

\begin{abstract}
Artificial meat has several features such as it can be formulated to have higher nutritional value than the original meat, more homogeneous, long-lasting storage (in dry condition), can be made without animal fat or cholesterol, contains a high content of unsaturated fatty acids which is good for health, and cheaper. The purpose of this community service activity was to improve the skills of cadres and women about the use of artificial meat from soybeans as a source of vegetable protein. The community service activity was conducted in the Syahmad District Office in Lubuk Pakam Sub-district which consisted of pre-intervention, intervention, and post-intervention activities. In the intervention stage, counseling and training in making artificial meat were carried out. The intervention results showed that women groups were capable and skilled in making artificial meat and understood the benefits of artificial meat from soybeans as a source of protein. The artificial meat from soybeans can be a source of vegetable protein for health and reduce degenerative diseases.
\end{abstract}

Keywords: Artificial meat, Soybeans, Counseling, Training

\begin{abstract}
Abstrak. Daging tiruan mempunyai beberapa keistimewaan,antara lain dapat atau diformulasikan sedemikian rupa sehingga nilai gizinya lebih tinngi dari daging asli,lebih homogen,tahan lama disimpan lama (dalam bentuk keringnya),dapat dibuat tidak mengandung lemak hewani atau kolesterol,sebaliknya tinggi kandungan asam lemak tidak jenuhnya sehingga baik untuk kesehatan dan harganya lebih murah. Tujuan kegiatan pengabdian pada masyarakat ini adalah untuk meningkatkan keterampilan kelompok kader dan ibu-ibutentang pemanfaatan daging tiruan dari kacang kedelai sebagai sumber protein nabati. Kegiatan pengabdian masyarakat dilakukan di Kantor Kelurahan Syahmad Kecamatan Lubuk Pakam yang terdiri dari kegiatan pra intervensi, intervensi, dan pasca intervensi. Pada kegiatan intervensi dilakukan penyuluhan dan pelatihan pembuatan daging tiruan.Hasil
\end{abstract}

*Corresponding author at: Politeknik Kesehatan Medan, Sumatera Utara

E-mail address: tiarlincebakara@gmail.com 
kegiatan intervensi menunjukkan kelompok ibu-ibu mempu dan terampil dalam membuat daging tiruan, serta memahami manfaat daging tiruan dari kacang kedelai sebagai sumber protein. Daging tiruan dari kacang kedelai ini dapat digunakan sebagai sumber protein nabati untuk kesehatan dan mengurangi penyakit degeneratif.

Kata Kunci: Daging tiruan, Kacang kedelai, Penyuluhan, Pelatihan Received 16 November 2018 | Revised 17 February 2019| Accepted 30 March 2019

\section{Introduction}

Animal-derived meat is an unprocessed source of animal protein which is not added with preservatives and has a high nutritional value because of its high content of protein, fat, minerals, and other nutrients that are needed by the body (SNI 3932/2008). The meat of cows, buffalo, goats, and other animals are the sourceof animal protein consumed by many people. In addition, meat is also a source of vitamin B12, iron and zinc minerals, and as the largest source of calories for humans [1].

The Central Bureau of Statistics (BPS) report in 2012 [2] stated that the average meat consumption in Indonesia reached $6,76 \mathrm{~kg} /$ year/capita or 18 grams per day. The results indicate that the daily protein needs of humans only met around 14\% of daily needs, while the average world population consumes $41.9 \mathrm{~kg} / \mathrm{year} / \mathrm{capita}$. The low consumption of meat in Indonesia is due to the high price of meat.

Some health problems that might arise due to excessive consumption of animal meat are including high cholesterol, heart attacks, and cancer. Previous studies showed that animal protein is not always better than vegetable protein because animal-derived meat is a source of animal protein. Furthermore, animal meat has much essential amino acid contents which cannot be synthesized directly by the human body but obtained from the outside. This encourages some people to quit the consumption of animal meat and choose to only eat vegetables or other vegetable ingredients [3].

The Food Agricultural Organization (FAO) in 2003 [4] explained that alternative protein foods derived from vegetable protein, such as beans, are more affordable than meat. It is even more convincing to switch from animal protein to vegetable protein because it is cheaper, improves the taste, and has many uses. One of the vegetable proteins is soybeans which are a good food ingredient for lowering cholesterol. Moreover, soybeans are also good for preventing high blood sugar because they have high fiber content and help prevent heart disease [5]. 
One effort to achieve national food security, especially the potential of local food ingredients such as food sources of beans, is the local varieties of soybeans. The differences between the local variety of soybeans and imported soybeans are that it has thinner skin, ripen faster, and has more water content [6,7]. A research by the Technology Assessment and Application Agency (BPPT) in 2012 comparing the superior local varieties of soybeans and imported soybeans found that the tofu processing with local varieties of soybeans tastes more delicious, has higher yields, and has lower risk to health because it is not a genetically modified organism (GMO) seed.

The "back to nature" lifestyle has been increasingly loved by the world community, especially in terms of food. This phenomenon encourages more people to direct their diet to plant-based foods. At present, many food technologies have been developed, especially various types of processed foods derived from meat, such as meatballs, steaks, and satay in terms of food diversification so that people can choose according to their needs. One of them is food derived from vegetable protein, namely artificial meat (meat analog).

The need for the type and quality of food products in the community has also increased and diversified which encourages the popularity of artificial meat which is considered to have some additional values such as it contains lower calories and saturated fatty acids than animal meat. The vegetable protein from beans has such properties that it is easily processed into flexible and supple fibers so that they can be formed to resemble meat fibers. Artificial meat is a product made from vegetable protein, which in principle all proteins can be processed into artificial meat [8].

Artificial meat has several features, such as it can be made or formulated to have higher nutritional value than the original meat, more homogeneous, and long-lasting storage (in dry form). In addition, it can be made without animal fat or cholesterol, has a high content of unsaturated fatty acids which is good for health, and cheaper. The development of diversification of food processing through processed artificial meat is strategic in supporting food security, especially in promoting various aspects of food availability, overcoming the problem of nutrition, and empowering the community economy.

The purpose of this community service was to improve the skills of cadres and women about artificial meat processing from soybeansand to increase their knowledge about the use and diversification of artificial meat as a source of vegetable protein. 
This activity aims to increase the income of farmers with catfish mina technology, to increase farmers' knowledge about integrated pest control, healthy rice cultivation, making organic feed, compost and organic pesticides.

\section{Method}

\section{Materials and tools}

The materials used in this activity were soybean flour, wheat flour, baking powder, and salt. The tools used in processing artificial meat were gas stoves, meat grinders, and cabinet dryers.

\section{Participants}

Participants in the community service activities were women group, also students and lecturers of nutrition department in the Medan Health Polytechnic.

\section{Implementation of Community Service}

The activities conducted at Syahmad Village consisted of pre-intervention, intervention, and post-intervention activities. The pre-intervention activities were:

1. Screening to obtain the target groups by providing an explanation of the purpose and benefits of the activities to the groups of cadres and women in Syahmad Village.

2. Establishing the target groups, namely cadres and women who were willing to participate in the community service activities by signing the form of willingness.

3. Conducting a pre-test with questionnaires which asked about the participants' knowledge of artificial meat from soybeans.

After the pre-test activities, the intervention activities were carried out in the form of training in making artificial meat and processing artificial meat into various processed meat products. The training was conducted in 2 hours with the following stages:

Stage I : Providing counseling in the form of public lectures using leaflet as the media. The counseling was conducted in Syahmad Village for 40 minutes, and the materials were:

a) Definition of artificial meat which is meat products made from flour which contain a source of protein, namely a mixture of flour from nuts and tubers,

b) Ingredients of artificial meat, namely soybean flour, wheat flour, salt, and baking powder,

c) Benefits and functions of artificial meat are including as a source of high protein, contains lower saturated fatty acids than animal meat, and has a high fiber and caloric value. 
d) Differences between artificial meat and fresh meat, in which artificial meat texture is more unified/homogeneous and cheaper than fresh meat. Furthermore, artificial meat is made from vegetable protein while fresh meat is derived from animal protein.

e) Advantages of artificial meat in which the nutritional content is higher than the original meat, it does not contain animal fat or cholesterol, the unsaturated fatty acid content is high, has a high caloric value, and contains lower saturated fatty acids than animal meat. In addition to its nutritional value, artificial meat also has several other features which are more homogeneous, more durable to be stored (in dry form), and low prices.

f) Procedure for making artificial meat was as follows:

- Making Soybean Flour

Soybeans were sorted by selecting beans whose shape and size were homogenous and then soaked in water for 9 hours, drained, and blanched at $100^{\circ} \mathrm{C}$ for 10 minutes, peeled from the bark, and dried in a cabinet dryer at $80^{\circ} \mathrm{C}$ for 9 hours. The dried soybean seeds were then ground using a blender until smooth and sifted into soybean flour.

- Making Artificial Meat

The ingredients for making $500 \mathrm{~g}$ soybean meat consisted of $60 \%$ soybean flour, $40 \%$ wheat flour, $5 \mathrm{~g}$ baking powder, $10 \mathrm{~g}$ salt, and clean water. Soybeans and wheat flour were mixed, added with water, and stirred to form a smooth mixture. Baking powder and salt were added while stirring until homogeneous. The resulting dough was then wrapped in a wet cloth for 5 hours. After that, the dough was washed with clean water. The result was a yellowish white round and rubber-like dough. The rubber-shaped dough was boiled at $100^{\circ} \mathrm{C}$ for 30 minutes to obtain artificial soybean meat.

Stage II : the implementation of training in processing artificial meat from soybeans and processing artificial meat into various forms of processed meat products, such as satay, steak, and meatballs to the target groups was held. During the training, a two-way discussion was also done in which both participants and trainers asked questions alternately.

Stage III : An organoleptic test of artificial meat products was carried out. The test was done directly by the training participants by giving an assessment of the preference for processed products from artificial meat, namely satay, meatballs, and steak from artificial meat. 
Post-intervention activities were the final activity after training. In this stage, a post-test was conducted in which participants knowledge was measured through questionnaires after the counseling and training on artificial meat. The questions in the post-test were the same as the questions in the pre-test.

\section{Evaluation of Activity Results}

An evaluation was done to assess the success of community service activities which have been conducted by looking at the pre-test and post-test results. The questions in the pre-test and the post-test were the same in which the questions were related to the ingredients for making artificial meat, benefits and functions of artificial meat, and procedure for making artificial meat and processed products from artificial meat. The time given to answer the questions in the pre-test and post-test for participants was 30 minutes.

\section{Result and Discussion}

\section{Pre-Intervention Activities}

Based on the screening results in the pre-intervention activities, 26 people were recruited from the target groups consisting of 19 cadres and 7 women from Syahmad Village. Before the intervention, the pre-test was conducted to determine the level of knowledge of the target groups about artificial meat from soybeans. The category of knowledge used was the ability to answer correctly all the questions given. The knowledge is classified good if the participants can answer 76-100\% questions correctly, sufficient if the participant can answer 56-75\% questions correctly, and poor if the participant can only answer 40-55\% questions correctly. Based on the pre-test results, the knowledge level of participants about artificial meat was only $7 \%$ which was categorized as poor knowledge.

\section{Intervention Activities}

In stage I, the counseling activity about artificial meat was held including the ingredients and making process, benefits, differences with animal meat, and processed products from artificial meat. The results of counseling activity showed the enthusiasm of the target groups for the materials provided, and it can be seen from the number of questions raised during the discussion.

In stage II, training was conducted on the making of artificial meat and artificial meat products. The training started with making soybean flour. The soybean flour products can be seen in Figure 1, while the artificial meat products can be seen in Figure 2. 


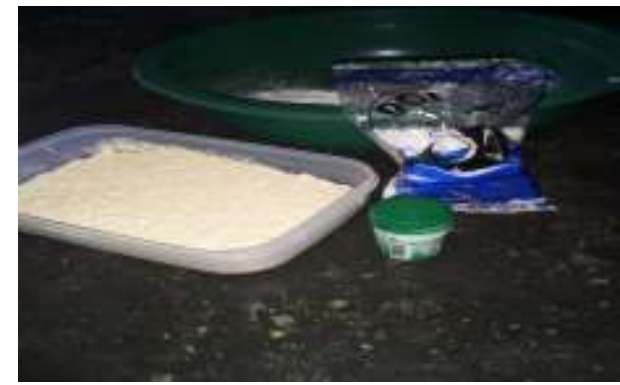

Figure 1. Soybean flour

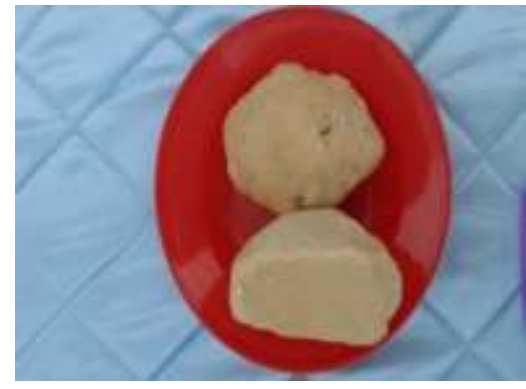

Figure 2. Artificial meat

The artificial meat was processed into satay, steak, and meatballs. The processing of satay was as follows: $500 \mathrm{~g}$ artificial soybean meat was cut into $2 \mathrm{x} 2 \mathrm{~cm}$, burned on fire for 10 minutes, and seasonings were put in the form of peanuts, soy sauce, and cayenne pepper (Figure 3).

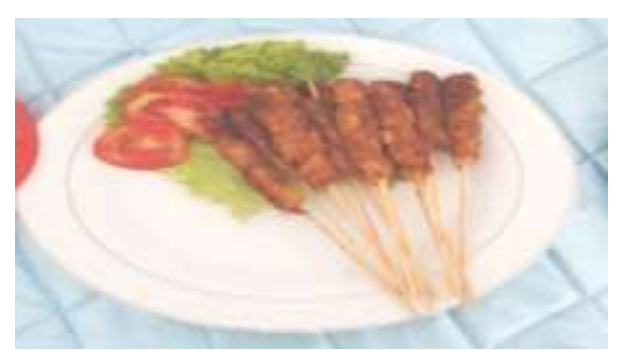

Figure 3. Satay from artificial meat

The processing of steak was as follows: artificial soybean meat was cut into a size of $4 \times 5 \mathrm{~cm}$, then soaked for 2 hours with coriander, pepper, and salt spices, and burned with a small ignition for 10 minutes. The resulting steak was served with tomato sauce (Figure 4).

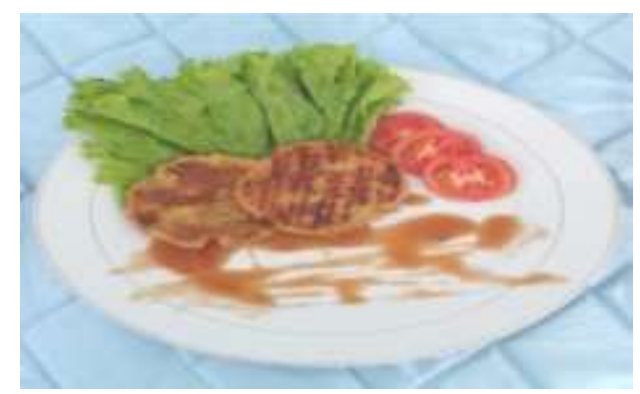

Figure 4. Steak from artificial meat

Making meatballs from artificial meat was as follows: $500 \mathrm{~g}$ artificial soybean meat was cut into smaller shapes and put into a food processor for grinding. After it was smooth, $15 \mathrm{~g}$ salt and $200 \mathrm{~g}$ ice were added. The mixture was ground, and tapioca flour was added until smooth. After that, $2 \mathrm{~g}$ pepper, $30 \mathrm{~g}$ garlic, and $100 \mathrm{~g}$ ice were added. The mixture was ground again until smooth. After looking smooth, the dough was shaped round using a hand and immediately put in hot water for 10 minutes at $95^{\circ} \mathrm{C}$. If all the 
doughs have been shaped into meatballs, the meatballs were boiled until cooked. The meatballs were considered as cooked if the meatballs were floating when boiled. Once cooked, the meatballs were removed and drained (Figure 5).

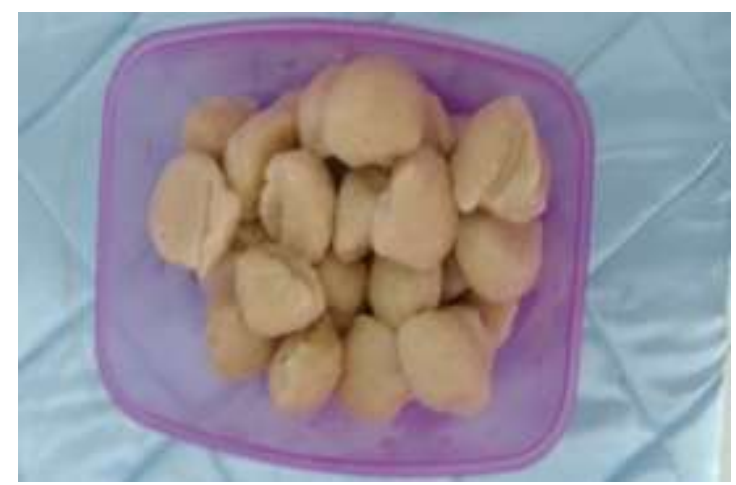

Figure 5. Meatballs from artificial meat

\section{Post-Intervention}

The post-intervention activities were the end of a series of counseling and training activities by giving a post-test to the participants using a questionnaire about their knowledge of artificial meat. The post-test results showed an increase in the community knowledge in which $81 \%$ of participants had a good knowledge of artificial meat.

\section{Conclusion}

The results of community service activities titled "Processing of Artificial Meat from Soybeans as a Protein Source in Cadres and Women Groups in Syahmad Village, Lubuk Pakam Sub-district" with a target of 26 women increased the level of community knowledge about artificial meat. The knowledge was including the ingredients for making artificial meat, the process of making and processing meat products, and the benefits of artificial meat from soybeans. At the beginning of the activity, the level of community knowledge about artificial meat was only 7\% (very poor), but their level of knowledge increased to $81 \%$ (good) after the intervention activities. The target groups have good knowledge about the use of artificial meat from soybeans, artificial meat processing, and diversification of artificial meat as a source of vegetable protein. Moreover, they can create appropriate technology in making artificial meat as a source of vegetable protein for health which can reduce degenerative diseases.

\section{References}

[1] Mc Afee A. J, McSorley E. M, Cuskelly G. J, Moss B. W, Wallace J. M, Bonham M. P, Fearon A. M. 2010. Red meat consumption: an overview of the risks and benefits. Meat Sci, 84 (1) : 1-13. doi : 10.1016/j.meatsci.2009.08.029. 
[2] Statistic Indonesia. 2012. Per Capita Weekly Average Consumption of Several Food Items, 2007-2018.

https://www.bps.go.id/statictable/2014/09/08/950/rata-rata-konsumsi-per-kapi ta-seminggu-beberapa-macam-bahan-makanan-penting-2007-2018.html (Accessed on 10 January 2019)

[3] Joshi V. K, and Kumar S. 2015. Meat analogues : Plant based alternatives to meat products - A review. Intl. J. Food Ferment. Technol. 5 (2): 107-119. doi : 10.5958/2277-9396.2016.00001.5.

[4] Greenfield H and Southgate D. A. T. 2003. Food Composition Data: Production, Management and Use. Food and Agriculture Organization od the United Nation, Rome.

[5] Chang J. H, Kim M. S, Kim T. W, and Lee S. S. 2008. Effect of soybean supplementation on blood glucose, plasma lipid levels, and erythrocyte antioxidant enzyme activity in type 2 diabetes mellitus patients. Nutr res Pract, 2 (3): 152-157. doi: 10.4162/nrp.2008.2.3.152.

[6] Antarlina S. S. 2002. Utilization of soybean improved variety and tapioca adding in tempeh production (in bahasa Indonesia). In: Arsyad D. M, Soejitno J, Kasno A, Sudaryono, Rahmianna A. A, Suharsono, Utomo J. S, editors. Technology kinerja to increase productivity of legumes and tuber crops, Bogor: Indonesian Center for Food Crops Research and Development; p.146-157.

[7] Ginting E, Antarlina S. S, and Widowati S. 2009. The suitability of improved soybean varieties for food industry ingredient (in bahasa Indonesia). $J$ Litbang Pertanian, 28 (3): 79-87.

[8] Astawan Made. 2009. Healthy with Nuts and Seeds (in bahasa Indonesia). Swadaya, Jakarta. 